\title{
ATLAS DE COLPOSCOPIA
}

\author{
Hemos recibido con dest̂ino a la Biblioteca de la Sociedad, el ATLAS DE COLPOSCOPIA, por \\ gentileza de su autor el Dr. José María Mateu-Aragonés.
}

EI Profesor Jaime Ramírez Sánchez Profesor de Ginecología y Obstetricia de la Universidad Nacional, hace el siguiente comentario del libro del Dr. Mateu-Aragonés:

El autor divide su obra en 10 capítulos, además de una bibliografía que comprende 565 referencias. En los dos primeros capítulos trata de las generalidades relativas al procedimiento, su nomenclatura y el recuento histológico y físiológico del cuello uterino normal. En los dos capítulos siguientes describe las alteraciones benignas del cuello, siguiendo hasta aquí las pautas señaladas en la literatura clásica sobre el tema.

En los capítulos $5^{\circ}$ y $6^{\circ}$ se refiere a las imágenes colposcópicas atípicas, englobando bajo el término de Leucoqueratosis a todas las clásicas "matrices de Hinselmann", tales como la leucoplasia, la base y el mosaico, modificación que introduce basado en el hecho de la gran similitud histológica que presentan estas imágenes. Por otra parte y de acuerdo a sus hallazgos, parece no existir mayor diferencia en cuanto a la significación clínica de estos cuadros. Dentro de las mismas imágenes colposcópicas atípicas, pero con un potencial de malignidad significativamente mayor, pasa a describir las eritroplasias, incluyendo en éstas la Zona de Transformación Atípica y la Erosio Vera.

Del mayor interés nos ha parecido el capítulo $7^{\circ}$, en el cual describe el autor las imágenes vasculares benignas y las atípicas, proponiendo una clasificación en 5 tipos, de creciente significación clínica en cuanto a sospecha de malignidad se refiere. Mateu-Aragonés concede a las modificaciones vasculares el mayor valor diagnóstico, criterio que compartimos plenamente, y cita 5 casos en los cuales "la irregularidad vascular ha sido el único dato que ha permitido levantar la sospecha de un carcinoma ante un cuadro colposcópico por lo demás banal".

Los capítulos $8^{\circ}, 9^{\circ}$ y $10^{\circ}$ se refieren a las Modificaciones Gravídicas del Cuello Uterino, la Utilidad de la Colposcopia y la Valoración Clínica, respectivamente, apartes todos del mayor interés, proponiendo en el último una clasificación de atipias en tres grados de gravedad progresiva, propuesta que consideramos muy recomendable por su sencillez y funcionalidad.

Por otra parte, presenta el autor una excelente colección de colpofotografías originales, correlacionándolas con los preparados histopatológicos correspondientes, a la vez que ajusta los conceptos clásicos colposcópicos a los anatomo-clínicos actuales. No sería justo, además, dejar de mencionar con los términos más elogiosos la presentación de la obra y la óptima labor editorial.

Por todo lo anterior no dudamos en recomendar la lectura del ATLAS DE COLPOSCOPIA, del Dr. José María Mateu-Aragonés, a todos los interesados en el tema, considerándolo como la mejor obra sobre la materia aparecida en lengua castellana. 